\title{
Relationship between Stress and Academic Performance: An Analysis in Virtual Mode
}

\author{
Janet Corzo Zavaleta ${ }^{1}$ \\ Departamento de Estudios Generales \\ Universidad de Ciencias y Humanidades \\ Lima, Perú
}

\author{
Roberto Yon Alva ${ }^{2}$ \\ Departamento de Estudios Generales \\ Universidad de Ciencias y Humanidades \\ Lima, Perú
}

\author{
Samuel Vargas Vargas 3 \\ Departamento de Estudios Generales \\ Universidad de Ciencias y Humanidades \\ Lima, Perú
}

Eleazar Flores Medina ${ }^{4}$

Departamento de Estudios Generales

Universidad de Ciencias y Humanidades

Lima, Perú

\author{
Yrma Principe Somoza ${ }^{5}$ \\ Departamento de Estudios Generales \\ Universidad de Ciencias y Humanidades \\ Lima, Perú
}

\author{
Laberiano Andrade-Arenas ${ }^{6}$ \\ Facultad de Ciencias e Ingeniería \\ Universidad de Ciencias y Humanidades \\ Lima, Perú
}

\begin{abstract}
This research work analyzes the relationship between stress and academic performance of engineering students at the University of Sciences and Humanities, in Peru, in the context of the pandemic. During this period, classes at the university were held virtually; and the difficulties that students present to carry out their classes were identified, such as lack of connectivity, family and financial problems and anxiety. The objective of the research is to analyze the relationship between stress and academic performance of engineering students. The work is part of a mixed approach, and data collection was carried out through interviews and surveys of engineering students based on the two variables identified: stress and academic performance. It began with a descriptive analysis, then moving on to inferential analysis to perform the hypothesis test. The SPSS was used for the reliability analysis using Cronbach's alpha with 0.84 as a result and validation by expert judgment with $84.5 \%$ acceptance. It was obtained as a result that between the Stress variable based on its three dimensions and academic performance there is not relationship since it was obtained that its $P$-value is greater than 0,05 ; it is concluded that stress is not only academic but also should consider others as labor, social. In addition, the positive stress that drives academic performance emerged. The beneficiaries with the research are students, and the university. It is concluded that there is no relationship between stress and academic performance.
\end{abstract}

Keywords-Academic performance; anxiety; stress; teachinglearning; virtual mode

\section{INTRODUCTION}

The health crisis that is being experienced around the world, due to the COVID-19 pandemic, has led various states to partially or totally close schools and universities to prevent the spread of the virus. In this context, the new educational challenge of virtual or distance education is imposed in almost all the countries of the world, bringing with it effects that not only represent a massive impact on productivity; but also, for social life and student learning [1]. Worldwide, it can be seen that the effects of social isolation and virtual education affect all students emotionally. According to the various studies carried out on this subject, it is evident that the majority of students have shown an increase in their levels of anxiety and stress, due to the drastic change around learning and future demands in the professional field [2]; to concern for their academic progress, performance, and their adaptation to distance learning. That is why the need for greater psychological counseling of students is emphasized [3].

In the new context of virtual education, the University of Sciences and Humanities (UCH) has implemented sundry measures that guarantee the achievement of the objectives proposed in the study plan. For this, it has implemented divers pedagogical resources available to teachers and students through the virtual platform that show good results; However, it has been shown that many of our students have expressed feelings of anxiety and stress that, in some cases, have led them to the determination to abandon their studies. This has been evidenced in the increase in the number of students who drop out; and although the university does not have reliable studies on this subject, teachers perceive this problem every day. The research work has as a unit of analysis, a student of the Faculty of Science and Engineering. In this Faculty, students manifest difficulties with connectivity, the internet, family problems due to the pandemic, as well as psychological problems. In this sense, it investigates the different manifestations of stress that may be affecting students in their academic performance.

Besides, the importance of the study is to be able to analyze the relationship between stress and academic performance, of our students from the Faculty of Sciences and Engineering, determining the levels of stress experienced by students and academic performance, in the virtual modality. For this, support mechanisms can be established for our students with comprehensive work with teachers and the educational community in general, based on the comprehensive training proposal. In this way, students will benefit, to improve their academic performance, and cope with stress through proposals that will come out of the research. Also, the university can avoid dropping out, which can be one of the causes of stress. Faced with the problem, formulate the following research question: What is the relationship between stress and academic performance of the students of the Faculty of Sciences and Engineering in times of pandemic?

The objective of the research is to analyze the relationship between stress and academic performance, of students of the Faculty of Sciences and Engineering of the UCH, in the virtual 
modality, in times of pandemic. For this, the degree of stress of university students is described in the virtual mode in times of pandemic; in addition, academic performance and its effects related to stress are analyzed.

The investigation is made up of six sections. In Section II, In the literature review; in Section III, the methodology was carried out; also in Section IV are the results; in Section V, the discussion, ending in Section VI with the conclusions and future work.

\section{LiterATURE REVIEW}

\section{A. Theoretical Basis}

1) Stress: As for the definition of stress, it is quite diverse and, until now, it has focused on a psychological approach, conceiving it as a disease that is associated with certain alterations of the organism [4]. However, stress can also be positive to face certain difficulties. The author [5] distinguished between pleasant stress, which he called stress; and stress or distress, when it comes to unpleasant stress. When it comes to stress, in general, it refers to anguish, but not everyone can relate to pleasant situations or events that have caused us stress: weddings, births, promotions, receiving awards, meeting old friends and many more. In that sense, any change, positive or negative, requires a response from our bodies to adapt and bring us back to our relatively peaceful state.

Stress is also seen as a state of imbalance between demands, be they from within or from external sources, and our perceived capacities to meet those demands. This is most acutely experienced when the expectation of meeting demands is not met, which will have consequences for the person.

In the academic field, the study of stress focuses mainly on a positivist stance, which leaves aside a phenomenological and qualitative look; that is, a holistic pedagogical approach that provides a comprehensive view of the phenomenon is not assumed. In order [4] to conceive the definition of stress in the academic field, it is necessary to take into account: both the psychobiological and the psychosocial components. According to what was stated by [6], academic stress is the process of change in the components of the teaching and learning process, through a set of individual and institutional adaptive mechanisms, a product of the overwhelming and demanded demand in the teaching and learning experiences that are developed in higher education institutions, with the purpose of maintaining a steady state in the educational process.

2) Academic Performance: Academic performance is a value associated with the quality of higher education institutions; since, it allows to have a better panorama of the educational reality; however, there are various criteria when measuring it. The concept of academic performance [7], must consider the diverse and complex factors that are revealed in learning; in this sense, academic performance is considered when there is a contribution in the achievement of student results, through evaluation. Likewise, it is pointed out that it is a multicausal phenomenon, which makes its assessment complex. Among the factors that intervene, they point to the components of internal and external order to the individual, which can be of a social, cognitive and emotional order.
In the case of stress and its relationship with academic development, studies indicate stress rates in university students, which are observed with greater preponderance in the first years of the degree and in evaluation periods. In addition, it has been shown that university students can present various stressful situations that affect their performance [8]. Regarding the relationship between stress levels and academic performance, there are numerous studies, such as those of [9] who carried out a study with 162 university students from the University of Balarias Islands (UIB), for which They used the Systemic Cognitive Inventory (SISCO) of academic stress as a measurement instrument. Among the main findings, it was reported that teacher evaluations and the jobs that teachers ask for are the main cause of stress in students; however, no direct relationship was found between stress and academic performance.

\section{B. Related Work}

This research work seeks to establish the relationship between stress and academic performance. For this, a search of the works related to this topic has been carried out, based on divers methodologies and results, which allows a broader overview of the problem studied.

In recent years, numerous studies have been conducted with various methodologies. For example [10], they identified the causes of stress and its effects on the academic performance of Malaysian Higher Education students. In this study, it is determined that life and interactions on campus are related to stress and academic performance. It is for this reason that the researchers suggest that university authorities guarantee suitable environments for learning and advisory centers [11].

The study carried out by [12] on stress in Astana Medical University, satisfaction and academic performance and online learning during the pandemic, carried out in a nursing school, reveals that for students learning during this period, in virtual mode, was stressful; and the perception of satisfaction was low and moderate. Regarding the academic performance of the students, they indicate that they were affected by the pandemic. Likewise, a significant and inverse correlation is shown between academic performance and stress during online learning [13].

On the other hand, the study carried out with students from the University of Nairobi, revealed that stress was related to academic performance; therefore, the majority of students stated that they had moderate to high levels of stress [14]. In the study carried out on the relationship between stress and academic performance, a high percentage of stressed students was obtained: about $65 \%$. Performance was statistically significant at ages ranging from 19 to 23 years. Besides, the linear regression was inverse; that is, the higher the stress, the lower the academic performance. To reduce this problem, it is recommended to carry out programs with academic workshops [15].

Although it has been proven in various studies, to establish the relationship between stress and academic achievement, there are other factors to take into account: physical and psychological aspects. In the study carried out by [16], on the effects of COVID-19 on the mental health of university students in the United States, an increase in stress and anxiety 
levels was reported. This increase was associated with multiple factors, such as fear and concern for their health, difficulty concentrating, disorders with sleep patterns, decreased social interactions and greater concern about their grades.

In the study carried out at the University of Pakistan, it is observed that the body mass index, stress and academic performance in students had a negative correlation of stress. Likewise, in order to calculate the process, the global system for data analysis (SPSS) was used [17]. According to the study carried out with Albanian students, on the averages of the students and their relationship with stress, the direct relationship between optimal academic performance and student tranquility was evidenced. Also, they used already elaborated questionnaires based on the stress scale and on attachment. The authors suggest that more in-depth research should be carried out, since the study was exploratory in its first phase [11].

The effects of the pandemic may increase dropout rates in educational institutions. Distance education, although not new, has been introduced on a large scale by trial and error to alleviate these effects; however, it has evidenced problems in learning and levels of understanding of students. In this sense, the recovery of this sector is essential to avoid a major generational catastrophe [18]; that is why higher education institutions have been forced to implement alternative methods to guarantee the continuity of studies and minimize the gap in this new context. For this purpose, the use of virtual platforms has been arranged with the objective that the actors of the educational process interact with each other, mainly teachers and students, and achieve the established curricular learning outcomes. This has meant a challenge to become familiar with the new teaching-learning methods; unfortunately many students state that they are not satisfied with this type of learning, increasing the rate of anxiety and depression [3].

It should be noted that the stress experienced by students is generated by academic and non-academic aspects such as: environmental, sociocultural and psychological factors. This means that students feel the pressure to perform well in order to meet the expectations of their parents and thus obtain benefits at work level in the future [19]. Specialists point out that academic stress can be decreased over time, and only a small portion of students will develop chronic disorders, if they do not receive medical help on time; this implies that the severity of the initial reactions to stress can predict their continuity and treatment [20].

It cannot be denied that stress influences academic performance; however, this can be reduced. On the one hand, through the decisions made by teachers and institutions, to facilitate the transition to the virtual modality, influencing the reduction of class hours, qualification requirements and support in evaluations. On the other hand, students also put in place various mechanisms to deal with it. They can be adaptive behaviors: acceptance and adaptive coping, or maladaptive ones like denial and disengagement [21]. On the other hand, students also put in place various mechanisms to deal with it. They can be adaptive behaviors: acceptance and adaptive coping, or maladaptive ones like denial and disengagement [2].

Likewise, students in this period have been forced, in many cases, to work to pay for their studies, which means a higher level of concern that affects their academic performance. In recent years, stress has been increasing moderately every year. According to the research between stress and performance, can observe that those who are exposed to work and academic hours their stress level increases considerably. Likewise, it has been shown that students who do not work their stress level is moderate. In summary, the authors found in the research that stress has different forms of manifestations; as well as the presence of positive stress is evidenced; the relationship between stress and academic performance was also found; however, more innovation is lacking in the uses of instruments to measure stress. In addition, positive stress must be related to academic performance, with an in-depth study to know the consequences of it.

\section{Methodology}

\section{A. Methodological Design}

The research work has a qualitative-quantitative approach, that is, mixed. This approach is often presented as two paradigms that complement each other to carry out a deeper investigation, with the perception and interpretation of the research data [22]. The research design is non-experimental, which is characterized by not manipulating the variable in the research [23]. Likewise, the research is descriptive, correlational, causal and cross-sectional in scope.

\section{B. Development of the Methodology}

The following steps were performed:

1) Modeling: A hypothetical model was carried out, between the variable stress and academic performance. According to Fig. 1, the relationships between them are observed, as an assumption, where the positive sign means that there is a direct relationship between the variables; and the negative sign, that there is an inverse relationship. That allows to be able to contrast, if there really is a correlation and if there is, what type it is, inverse or direct.

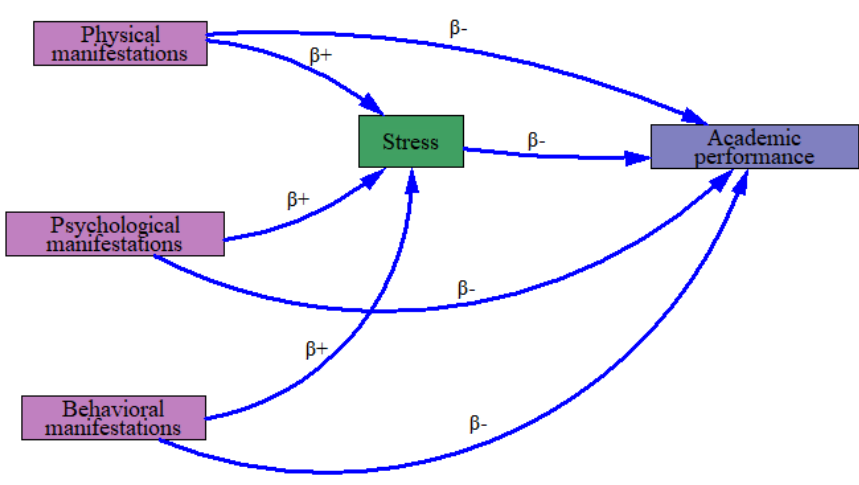

Fig. 1. Hypothetical Model.

2) Interview: 8 students from the 1st to 4 th cycle of the Faculty of Engineering were interviewed. For this, the following steps were taken into account (see Fig. 2).

- Elaboration of the questions. 
- $\quad$ Selection of students.

- Recording the interview.

- Analysis of the interview.

A semi-structured interview with 6 questions was conducted, as shown in Table I.

TABLE I. INTERVIEW QUESTIONS GUIDE

\begin{tabular}{cl}
\hline \hline Questions & \\
\hline 1 & $\begin{array}{l}\text { During your academic preparation at the university, } \\
\text { have you felt stress? If you have felt stress, } \\
\text { how do you think it affects your studies? }\end{array}$ \\
\hline 2 & $\begin{array}{l}\text { When you are stressed for academic reasons, do you have } \\
\text { health problems such as pain, insomnia, indigestion or others? } \\
\text { If yes, can you specify which ones and how they are } \\
\text { manifested? }\end{array}$ \\
\hline 3 & $\begin{array}{l}\text { In periods of stress, do you usually have problems on } \\
\text { an emotional level, that is, in your mood, your feelings, } \\
\text { lack of concentration or others? If yes, } \\
\text { can you specify which ones and how they are manifested? }\end{array}$ \\
\hline 5 & $\begin{array}{l}\text { During the last semester, you were seized with feelings of depression } \\
\text { and / or sadness In what newspapers specifically? } \\
\text { How are you coping? }\end{array}$ \\
\hline 5 & How do you perceive stress affects your participation in class? \\
\hline \hline
\end{tabular}

3) Survey: For this study, a survey has been prepared, based on the SISCO questionnaire on stress. In Peru, in recent years, several studies have been carried out on stress in students based on the SISCO SV-21 inventory. Among these works, have [24] who analyzed the psychometric evidence of the SISCO SV-21 inventory in 560 students from public and private universities in Metropolitan Lima; reaching the conclusion that said inventory gathers the evidence of validity and reliability for its use [25].

In the present work, the survey was applied using the Google form questionnaire as an instrument. The student population under study is 150 students from the first to the fourth cycle. Through a simple random sample, 109 students were obtained from the morning and night shift.

In addition, the academic performance variable was analyzed by placing intervals to the average grades from 0 to 20 , considering the levels very low, low, regular, and high and very high. This information was obtained from academic records; This consists of their average grades from the first stage of the 2021-2 semester (see Table II).

TABLE II. Average Note RANGe

\begin{tabular}{|c|c|c|}
\hline Scale & Academic performance & Average note range \\
\hline 1 & Very low & {$[0 ; 5[$} \\
\hline 2 & Low & {$[5 ; 11[$} \\
\hline 3 & Regular & {$[11 ; 15[$} \\
\hline 4 & High & {$[15 ; 18[$} \\
\hline 5 & Very high & {$[18 ; 20]$} \\
\hline
\end{tabular}

\section{RESUlts}

\section{A. Instrument Reliability and Validation}

- Reliability with Cronbach's Alpha

The instrument's reliability result must be greater than 0.70 for it to be approved (see Table III) [26]; since the value must range between 0 and 1 [27] [28]. The reliability of the instrument was determined with $10 \%$ of the population. For this, the data were collected and processed with the SPSS program. The result was 0.84 . The analysis of questions 1 to 17 of Table IV shows that if a question is deleted from the survey, the Cronbach's alpha varies between 0.82 and 0.85 . That is, it is within the mean of Cronbach's alpha, which is 0.84. From the penultimate column of Table IV, its values must be greater than 0.200 . It is observed that questions 2 and 5 do not comply; for this the modification was made.

TABLE III. INTERVAL FOR RELIABILITY

\begin{tabular}{|l|l|}
\hline Interval & $\begin{array}{c}\text { Reliability } \\
\text { assessment }\end{array}$ \\
\hline$[0 ; 0,5[$ & Unacceptable \\
\hline$[0,5 ; 0,6[$ & Poor \\
\hline$[0,6 ; 0,7[$ & Weak \\
\hline$[0,7 ; 0,8[$ & Acceptable \\
\hline$[0,8 ; 0,9[$ & Well \\
\hline$[0,9 ; 1]$ & Excellent \\
\hline
\end{tabular}

TABLE IV. ALFA DE CRONBACH

\begin{tabular}{|l|l|l|l|l|}
\hline Questions & $\begin{array}{l}\text { Mean } \\
\text { scale } \\
\text { if item } \\
\text { has been } \\
\text { sup- } \\
\text { pressed }\end{array}$ & $\begin{array}{l}\text { Scale } \\
\text { variance } \\
\text { if item } \\
\text { has been } \\
\text { sup- } \\
\text { pressed }\end{array}$ & $\begin{array}{l}\text { Total } \\
\text { correla- } \\
\text { tion of } \\
\text { corrected } \\
\text { elements }\end{array}$ & $\begin{array}{l}\text { Cronbach's } \\
\text { alpha if } \\
\text { the item } \\
\text { has been } \\
\text { sup- } \\
\text { pressed }\end{array}$ \\
\hline 1 & 32,00 & 57,78 & 0,31 & 0,83 \\
\hline 2 & 33,40 & 61,52 & 0,09 & 0,84 \\
\hline 3 & 31,75 & 56,30 & 0,45 & 0,83 \\
\hline 4 & 32,15 & 53,61 & 0,50 & 0,83 \\
\hline 5 & 33,15 & 61,61 & 0,04 & 0,85 \\
\hline 6 & 32,25 & 51,67 & 0,75 & 0,81 \\
\hline 7 & 33,35 & 56,13 & 0,54 & 0,83 \\
\hline 8 & 32,75 & 57,57 & 0,30 & 0,84 \\
\hline 9 & 32,50 & 53,32 & 0,60 & 0,82 \\
\hline 10 & 32,15 & 53,50 & 0,73 & 0,82 \\
\hline 11 & 32,65 & 55,82 & 0,48 & 0,83 \\
\hline 12 & 32,65 & 55,29 & 0,33 & 0,84 \\
\hline 13 & 33,30 & 57,38 & 0,42 & 0,83 \\
\hline 14 & 33,55 & 58,37 & 0,62 & 0,83 \\
\hline 15 & 32,80 & 53,75 & 0,61 & 0,82 \\
\hline 16 & 33,60 & 58,67 & 0,63 & 0,83 \\
\hline 17 & 32,80 & 52,91 & 0,48 & 0,83 \\
\hline & & & & \\
\hline
\end{tabular}

- Validation by Expert Judgment

Expert judgment was carried out to validate the contents of the instrument [29], (see Table V). The profile of the experts that was considered for the validation was: specialists in psychology and education who work at the university. The validation by expert judgment was taken as a reference for approval, greater than $75 \%$. As a result, $84.7 \%$ acceptance was obtained as the average of all the questions evaluated. For this, the following criteria were taken into account: clarity, updating, coherence, consistency, objectivity, content and sufficiency.

\section{B. Qualitative Analysis}

According to the interviews carried out with the students from the first to the fourth cycle of the Faculty of Sciences and Engineering, the following categories could be constructed. 


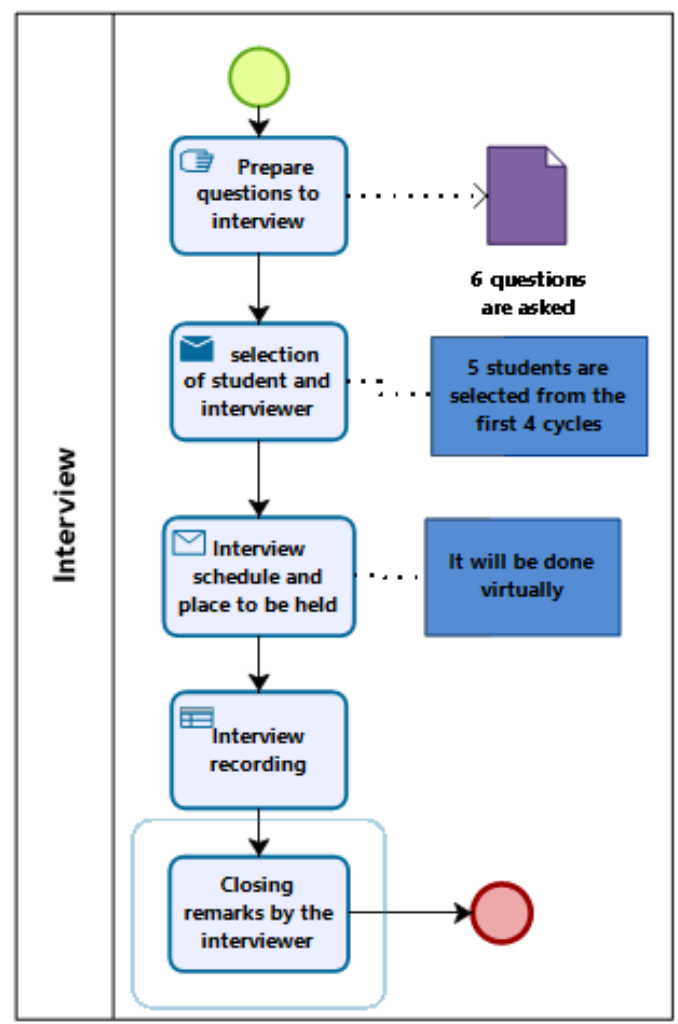

Fig. 2. Steps of an Interview.

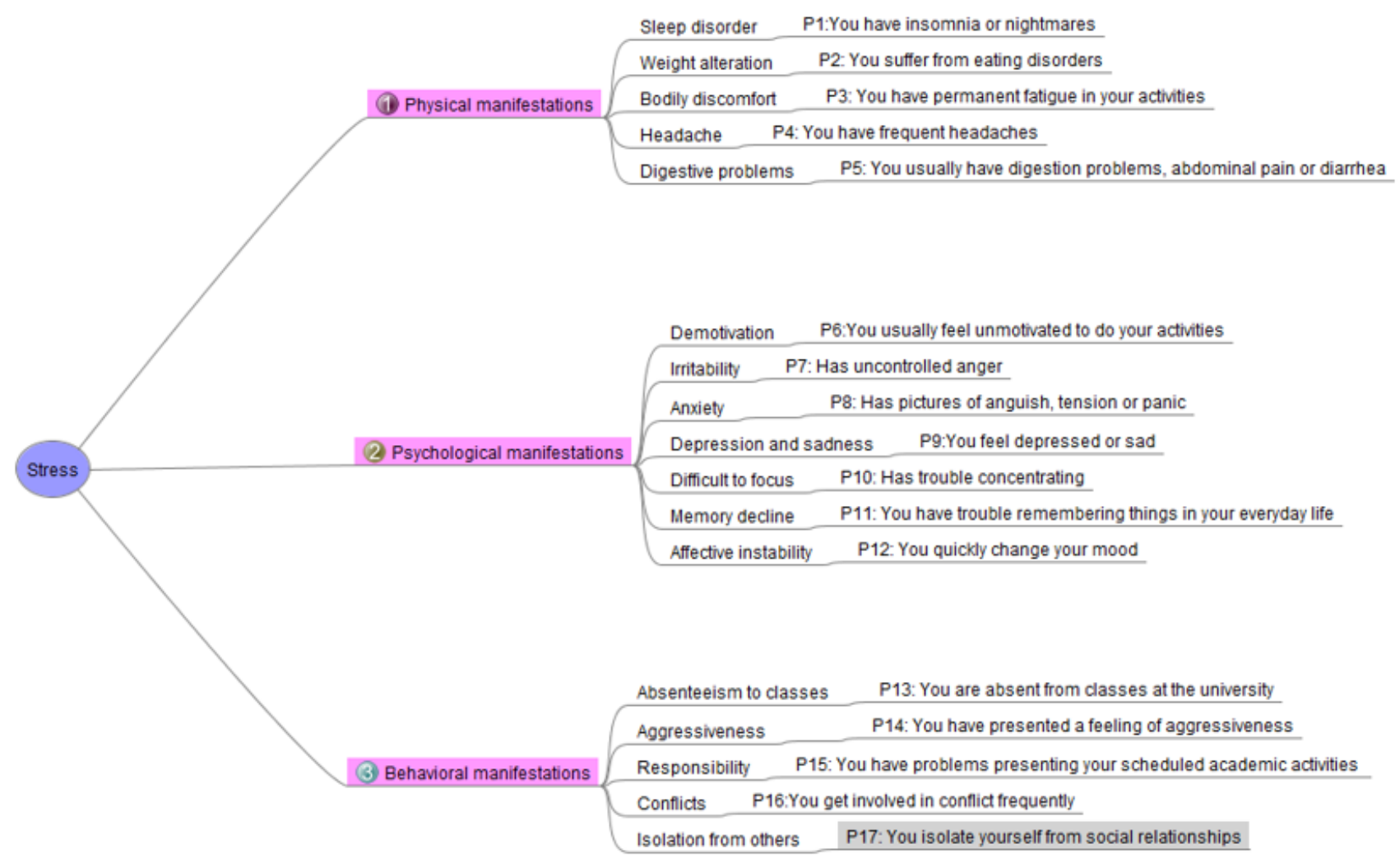

Fig. 3. Dimensions of the Stress Variable. 
TABLE V. EXPERT JUDGMENT

\begin{tabular}{|c|c|c|c|c|}
\hline Question & Expert1 & Expert2 & Expert3 & Percent \\
\hline 1 & $80 \%$ & $85 \%$ & $90 \%$ & $85 \%$ \\
\hline 2 & $75 \%$ & $80 \%$ & $85 \%$ & $80 \%$ \\
\hline 3 & $70 \%$ & $90 \%$ & $80 \%$ & $80 \%$ \\
\hline 4 & $90 \%$ & $90 \%$ & $90 \%$ & $90 \%$ \\
\hline 5 & $80 \%$ & $80 \%$ & $80 \%$ & $80 \%$ \\
\hline 6 & $90 \%$ & $90 \%$ & $90 \%$ & $90 \%$ \\
\hline 7 & $70 \%$ & $90 \%$ & $80 \%$ & $80 \%$ \\
\hline 8 & $90 \%$ & $90 \%$ & $90 \%$ & $90 \%$ \\
\hline 9 & $80 \%$ & $85 \%$ & $90 \%$ & $85 \%$ \\
\hline 10 & $75 \%$ & $80 \%$ & $85 \%$ & $80 \%$ \\
\hline 11 & $70 \%$ & $90 \%$ & $80 \%$ & $80 \%$ \\
\hline 12 & $90 \%$ & $90 \%$ & $90 \%$ & $90 \%$ \\
\hline 13 & $80 \%$ & $80 \%$ & $80 \%$ & $80 \%$ \\
\hline 14 & $90 \%$ & $90 \%$ & $90 \%$ & $90 \%$ \\
\hline 15 & $70 \%$ & $90 \%$ & $80 \%$ & $80 \%$ \\
\hline 16 & $90 \%$ & $90 \%$ & $90 \%$ & $90 \%$ \\
\hline 17 & $90 \%$ & $90 \%$ & $90 \%$ & $90 \%$ \\
\hline
\end{tabular}

1) Stress and Academic Performance Relation: All students report feeling stress during their academic preparation; but they point out that this occurs in specific periods when they approach the date of the evaluations; or in some courses they don't understand. At this point they coincide in cases of students who work and study, they more accurately recognize the symptoms of stress. Likewise, students recognize that stress affects their studies, as it causes them to lack concentration and lack of motivation. As stated by [30], academic stress can reduce academic performance, decrease motivation and increase the risk of dropping out of school.

E1: Yes, definitely especially in these times of the pandemic was when I decided to study and the moments of greatest stress ehh I think are the evaluations and when jobs are put together ... duties that I have to perform at work sometimes I am short on the time ... I think that in part yes because ... I am very stressed or ... I am not sometimes like I lose motivation.

2) Physical Manifestations: In the student's discourse, it stands out that most have presented physical symptoms due to stress. The main physical manifestations are headache, insomnia, palpitation of the eyes and digestive problems. These findings coincide with that reported by Silva et al. [31], where it was found that the physical manifestations of stress are headaches or migraines and an increase or decrease in food consumption. These symptoms occur in short intervals and can usually be managed without the need for medical treatment.

E3: Yes, when I am under stress I have headaches, not always ... headaches or insomnia. The headache lasts for hours, not long, but regular. I mostly control it when I start to calm down

3) Psychological Manifestations: All students present emotional manifestations as a consequence of stress. They usually present anxiety, reluctance, lack of motivation, sadness and anger [32]. These symptoms appear in short periods and may be associated with comprehension problems; or to the development of various activities at an economic and academic level. It should be noted that anxiety at the academic level may be due to the courses that they consider more difficult or the expectation of their grades, since they consider that they are assigned a low grade and that it is not related to the effort made.
E4: Some anxiety. There comes the issue of anxiety sometimes there are days that I have to stay up late to be able to review or the same issue of knowing what I am going to do the next day as I am going to leave to be able to do the different activities generates stress, generates anxiety more than anything, well it is linked to stress ... and my mind is going elsewhere.

4) Behavioral Manifestations : Most students participate in various classroom activities, depending on the courses. While some interviewees indicate that they prefer not to participate, as they consider that it is not necessary because they know the issues. Given this, can indicate that there is not direct relationship between stress and participation in activities developed in class. These results are complemented by those presented by Encina Meza et.al. [33] who points out that in stressful situations, the most frequent behavioral symptoms are lack of concentration, decay, isolation and the tendency to feel more conflictive and with a tendency to argue. In this sense, can point out that in terms of aggressiveness, conflict and social relationship problems between students, a direct relationship with stress is not observed. However, some students emphasize that group work can generate stress, due to the fact that not all participate actively and certain communication problems.

E4: ...perhaps that out there there are not all cases of a student who perhaps are the ones who want to do everything according to their interpretation and maybe out there they are a little susceptible to changes, but after I have crashed, I have felt rather like Many of them are also young, as they look for some support from people who are of age, I see that sometimes they lean on me in some things.

\section{Emerging Categories}

1) Stressors: It was identified that the most frequent stimuli that generate stress are evaluations, overload of activities and work; added to this is the limited time to perform them. On the other hand, it is observed that students present greater stress in the periods close to the evaluations; since they feel pressured to pass the courses, and their expectations may be offset by their results. These results correspond to those presented by Cordova et al. [34]. Who point out that within the demands of the academic environment, the ones that generate the most stress for the student are overload of tasks, type of work and evaluations. Besides, several of the students indicate that they are not organized properly; therefore, they are joined by various jobs and evaluations that they feel they will not be able to fulfill.

E1: but the previous cycle if from the midterm exam and until the final exam I had these symptoms.

Likewise, we observe that the courses that generate the greatest stress are those related to formal sciences: mathematics, physics and those of the specialty of engineering.

E6: mostly because of the area that was mathematics and that was systems. Then it got a bit complicated and I kind of left your mind blank.

2) Coping Strategies: Within the interviews, it has been observed that students test various stress coping strategies. These strategies focus on direct actions after personal evaluation and analysis, before seeking support from external elements. 
This coincides with the findings obtained by Boullosa [35], who points out that the techniques most used by students to overcome stress are to strive to achieve their academic goals by concentrating on solving the problem and looking for spaces for relaxation. Most of them indicate that they handle the situation personally, without resorting to external help, since they consider that they are prepared to cope with this situation. Some techniques they use are trying to calm down or think about positive aspects of their preparation, doing an activity that they like or resorting to a metacognitive strategy to evaluate their learning process.

E1: First I try to calm down, I try to see the positive side of that of the situation and for another opportunity to do it much better.

However, a small number of students indicate that they have resorted to interpersonal relationships as a coping strategy; that is, to family or some belief. These findings are related to the study conducted by Barraza [36], who points out that the strategies most used by students are the elaboration of a plan, execution of tasks or activities, and assuming these stressful situations with humor; while the least used are praising their progress or religiosity.

E3: Not the other way around, they try to support me (my family) but at the moment I am with all the stress ... and I get defensive but it can be controlled.

E7: ehhh, I do it by myself; bone also raised a small prayer also as it is called, I say to God give me strength, please ...

3) Positive Stress: According to Díaz \& Fierro [37], positive stress or eustress is a positive physiological and emotional response to academic stressors, which are perceived by the student as a challenge or challenge and not as a threat. In this sense, it is pointed out that the resources available to the student allow them to respond to academic demands and strengthen their skills. Besides, some students point out that stress can be positive for the development of their academic activities, since it motivates them and provides them with that "pressure" necessary to achieve their academic goals.

E6: no, because of ... with this pressure I feel that I have to study more and about going out so that next week I have good results.

\section{Descriptive Analysis}

The survey is made up of two sections: in the first, the sociodemographic data, such as age, sex, cycle, shift; and in the second section, the questions of the stress variable that have 3 dimensions with 17 questions (see Fig. 3). These were built with the Lickert scale, where 1 is never; 2 hardly ever; 3 sometimes; 4 usually; y 5 always. It is observed in Fig. 4 , the gender and age of the student with its frequency, being the male gender the one that predominates over the female; likewise, the most frequent age is 21 years and 1 student over 50 years of age. Regarding the female students surveyed, 9 are 20 years old more frequently and one student is 40 years old. An asymmetric bell with accumulation between 17 and 21 years old is evidenced in both graphs, both for male and female, with greater frequency and the others are scattered. Likewise, in Fig. 6 it is observed that the average of the male and female gender are close to 2,10. The one with the greatest amplitude of length of the stress average is in females, with a range of 1.90 to 2,28 and in the male gender, the length of their stress averages is 2 to 2,15 .

In Fig. 5 the dimensions of the stress variable were analyzed, where the three obtained a median close to 2 , with respect to the average stress score. Además en la Fig. 7, it is observed that $16,85 \%$ have high stress; analyzing the moderate percentage, it is wide with $57,30 \%$ where the majority of students remain neither very high nor very low. Relating to the percentage of academic performance, $45,96 \%$ is high and what is shown in Table VI the percentages of the stress dimensions is moderate, concluding that stress and performance in both is on the moderate average. Besides, the analysis of academic performance was carried out by means of the average grades of the students from the first to the fourth cycle of the students of the Faculty of Engineering. The mean of 3,90 indicates that it is above the average, it means that the students have a high average close to $46 \%$, the low average is little significance, since it is approximately $5 \%$ (ver Fig. 8).

TABle Vi. Percentage of Stress

\begin{tabular}{|c|c|c|c|}
\hline Dimensions & Low & Moderate & High \\
\hline Physical manifestations & $30,34 \%$ & $50,56 \%$ & $19,10 \%$ \\
\hline Psychological manifestations & $25,84 \%$ & $55,06 \%$ & $19,10 \%$ \\
\hline Behavioral manifestations & $25,84 \%$ & $51,69 \%$ & $22,47 \%$ \\
\hline
\end{tabular}

\section{E. Comparison Analysis of Gender Means by Dimensions}

Through statistical analysis, the Mann-Whitney U test was performed for sample variables, which corresponds to the male and female gender, with respect to the dimensions of the investigation, (see Table VII). It is observed that the P-value is 0,140 of the first dimension. By theory it is known that if the Pvalue is less than 0,05 there is a difference of the means in the comparison and if it is greater than 0,05 there is no difference between the averages.In this sense, in the 3 dimensions, the $\mathrm{P}$-value is greater than 0,05 ; therefore, it is concluded that in the three dimensions the means are not different since their $\mathrm{P}$-value for the 3 is greater than 0,05 , with a margin of error above $5 \%$.

\section{F. Relationship between Variables}

The relationship between all the variables of the Stress dimensions was made, using Spearman since it is nonparametric. From Table VIII it is observed ** means that the correlation is significant at the 0,01 level (bilateral); where is interpreted as $1 \%$ margin of error. In the Table IX, the scale of the correlation coefficient is observed; comparing with the results obtained, the dimension of psychological manifestations and with physical manifestations is $0,512 * *$; that is, moderate positive correlation. Likewise, the dimension behavioral manifestations with physical manifestations is obtained $0,647 * *$ which is in the range of correlation, moderate positive and finally the dimension behavioral manifestations with psychological manifestations is $0,816^{* *}$, being in the range of high positive correlation. It is observed in the Table IX highlighted in blue, the range where the results obtained are found. On the other hand, the relationship between the academic performance variable and the 3 dimensions of stress is observed where the result is very low. In Table VIII it is 


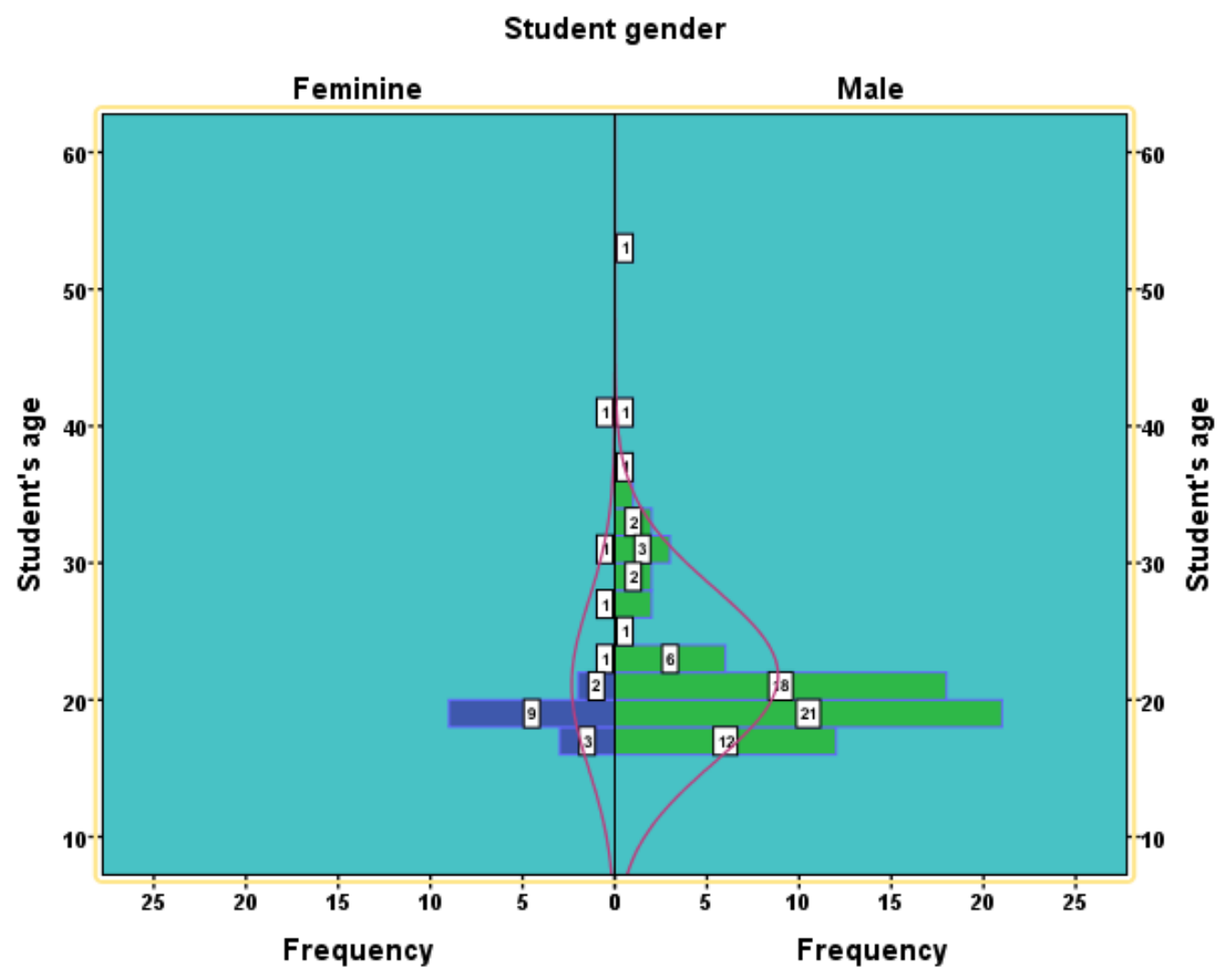

Fig. 4. Analysis of Gender and Age.

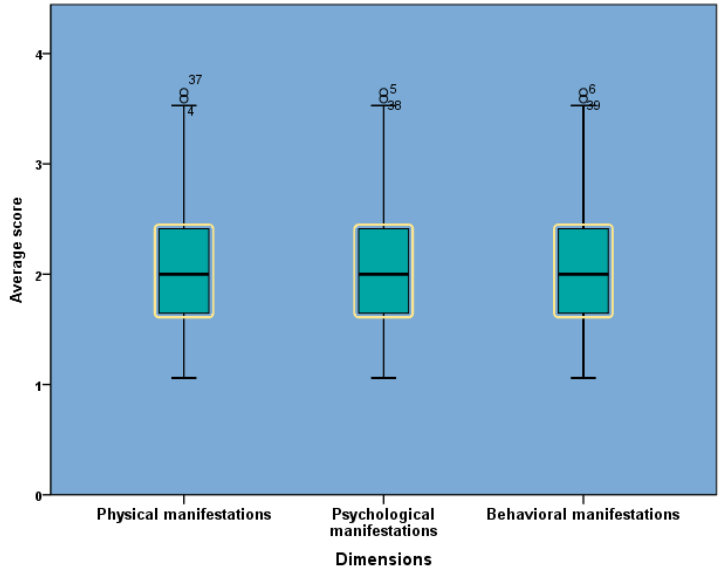

Fig. 5. Analysis by Dimensions. are inverse but very low, that is, the greater the stress, the less academic performance, but it is very low; this can be verified with Fig. 8 where 45,96\% academic performance is high and in Fig. 5 where the 3 dimensions of stress are not higher than the average.

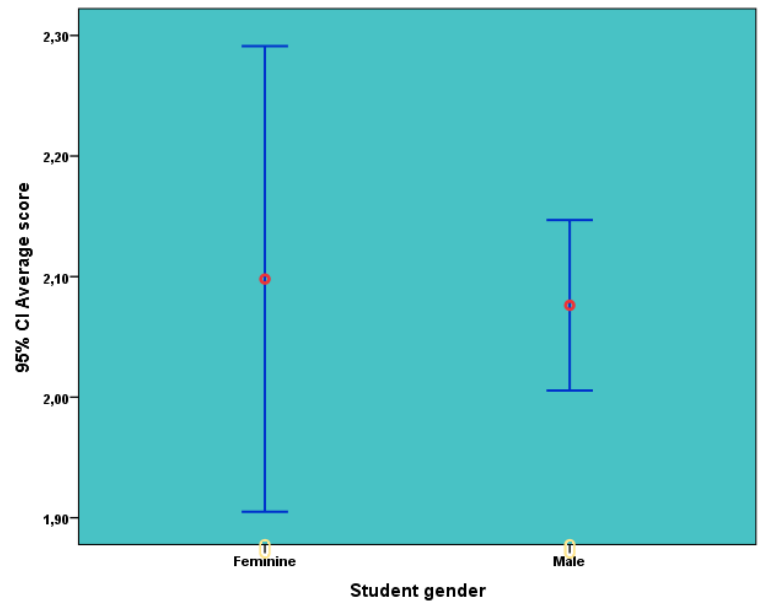

Fig. 6. Confidence Interval Analysis.

TABLE VIII. RELATIONSHIP BETWEEN VARIABLES

\begin{tabular}{|l|c|c|c|c|}
\hline Variables & $\mathbf{1}$ & $\mathbf{2}$ & $\mathbf{3}$ & $\mathbf{4}$ \\
\hline 1.Academic performance & 1 & & & \\
\hline 2. Physical manifestations & 0,076 & 1 & & \\
\hline 3. Psychological manifestations & $-0,106$ & $0,512^{* *}$ & 1 & \\
\hline 4. Behavioral manifestations & $-0,108$ & $0,647^{* *}$ & $0,816^{* *}$ & 1 \\
\hline
\end{tabular}




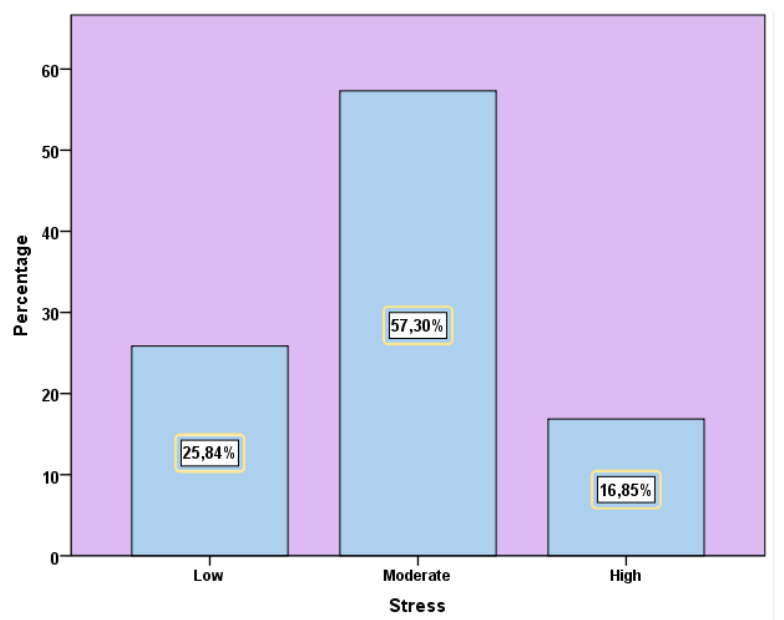

Fig. 7. Student Stress.

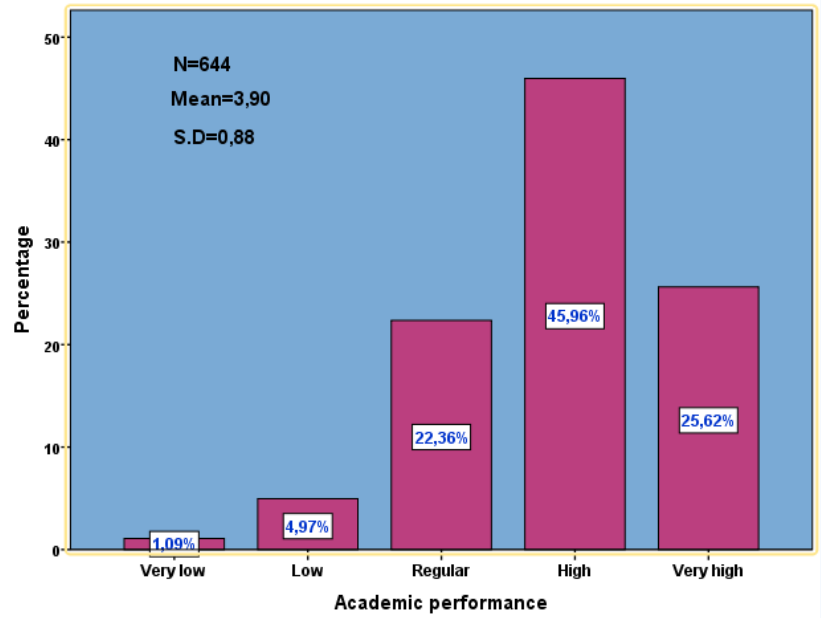

Fig. 8. Academic Performance of Students.

\section{G. Multiple Linear Regression}

It is observed in the Table $\mathrm{X}$ the predictor variables that are the dimensions of the stress variable and where academic performance is the dependent; it is observed that the significance is greater than 0.05 in the three dimensions of stress. It is stated then that none of the three dimensions of the stress variable is related to academic performance. Besides, $R^{2}=0,040$ indicates that $4 \%$ of the academic performance variable is explained by the variables of the Stress dimensions. Analyzing the value of Beta for the prediction of the variables under study, it was found that the beta of the physical and psychological manifestations are positive, that is, but very low, observing the significance greater than 0,05 , concluding that there is not relationship; that of psychological manifestations is close to one its significance value, that is, there is not relationship in a determining way.
TABLE VII. COMPARISON OF MEANS OF 2 INDEPENDENT SAMPLES

\begin{tabular}{|l|l|c|c|}
\hline \multicolumn{1}{|c|}{ Dimensions } & Gender & $\mathbf{Z}$ & $\mathbf{P}$ \\
\hline $\begin{array}{l}\text { Physical manifes- } \\
\text { tations }\end{array}$ & Male & $-1,475$ & 0,140 \\
\cline { 2 - 2 } & Femenine & & \\
\hline $\begin{array}{l}\text { Psychological } \\
\text { manifestations }\end{array}$ & Male & $-0,341$ & 0,733 \\
\cline { 2 - 2 } & Femenine & & \\
\hline $\begin{array}{l}\text { Behavioral mani- } \\
\text { festations }\end{array}$ & Male & $-0,906$ & 0,365 \\
\cline { 2 - 2 } & Femenine & & \\
\hline
\end{tabular}

TABLE IX. SCALE of VALUES OF THE CORRELATION COEFFicient

\begin{tabular}{|c|l|}
\hline Value & \multicolumn{1}{|c|}{ Meaning } \\
\hline-1 & Large and perfect negative correlation. \\
\hline$-0,9$ a $-0,99$ & Very high negative correlation. \\
\hline$-0,7$ a $-0,89$ & High negative correlation. \\
\hline$-0,4$ a $-0,69$ & Moderate negative correlation. \\
\hline$-0,2$ a $-0,39$ & Low negative correlation. \\
\hline$-0,01$ a $-0,19$ & Very low negative correlation. \\
\hline 0 & Null correlation. \\
\hline 0,01 a 0.19 & Very low positive correlation. \\
\hline 0,2 a 0,39 & Low positive correlation. \\
\hline $\mathbf{0 , 4}$ a $\mathbf{0 , 6 9}$ & Moderate positive correlation. \\
\hline $\mathbf{0 , 7}$ a $\mathbf{0 , 8 9}$ & High positive correlation. \\
\hline 0,9 a 0,99 & Very high positive correlation. \\
\hline 1 & Large and perfect positive correlation. \\
\hline
\end{tabular}

\section{TABLE X. Multiple Linear REgRession}

\begin{tabular}{|c|c|c|c|}
\hline \multirow[t]{2}{*}{$\begin{array}{l}\text { Predictor variable: } \\
\text { The } 3 \text { dimensions of the } \\
\text { stress variable }\end{array}$} & \multicolumn{3}{|c|}{$\begin{array}{c}\text { Dependent variable: } \\
\text { Academic perfomance } \\
R^{2}=0,040\end{array}$} \\
\hline & Beta & $\mathbf{t}$ & Sig. \\
\hline Physical manifestations & 0,235 & 1,686 & 0,095 \\
\hline Psychological manifestations & 0,012 & 0,067 & 0,947 \\
\hline Behavioral manifestations & $-0,249$ & $-1,199$ & 0,234 \\
\hline
\end{tabular}

\section{DISCUSSION}

In the research it was obtained that the relationship between stress and academic performance is very low. This may have an explanation, that stress is not unique to academics; in other words, there are other forms of stress, such as work stress, psychosocial stress and others, product of the pandemic.The academic performance in times of pandemic, with distance classes, in the students of the Faculty of Engineering is high and very high with a percentage of $45,92 \%$ and the stress dimensioned in the physical, psychological and behavioral aspects has an average result regular. If compare with the study carried out by [38] on stress and academic performance, they found that if there is an inverse relationship between these 2 variables under study. However, his study was in another context, where there was no presence of the COVID19 pandemic. They obtained a moderate stress, approximately $72 \%$ of students; on the other hand, the research carried out in the article is approximately 50\%. In the research, students from the morning shift but also the night shift were surveyed where almost all students work, and may also have work stress, since they do it remotely. This last variable was not considered in the research. 


\section{CONCLUSION AND FUTURE WORK}

According to the quantitative study, it is observed that there is not relationship between stress and academic performance; where the average of the students is high and very high with $45,96 \%$ and the stress of the 3 grouped dimensions is moderate with $57,30 \%$. However, students report feeling stress in their academic preparation. Stress manifests itself on a physical level, mainly with headaches and insomnia, with $50,56 \%$ of the moderate form; psychologically, with anxiety, demotivation and sadness; but this does not directly affect their interpersonal relationships; obtaining a 55,06\% in the moderate way and in the behavioral manifestations a $51,69 \%$. The students indicate that the periods close to the evaluations generate more stress at the academic level; as well as the pressure to pass the subjects, mainly those of science that are considered the most complex. To cope with stress and anxiety, they resort to direct strategies, based on a personal analysis without resorting to external elements. On the other hand, it should be noted that stress is positive to the extent that it allows us to respond correctly to demands or difficulties. In addition, it is observed in students that stress is used as a kind of fuel to achieve their academic goals. There is a relationship between the three dimensions of the stress variable.

The methodology carried out with the techniques of surveys and interviews, allowed to have a holistic panorama of being able to analyze and cross information in the investigation. New studies are suggested in relation to positive stress and academic performance in university students. Also, delve into the situation generated in the teacher as part of teaching in the virtual mode. On the other hand, analyze the subject from a qualitative methodology that allows us to know the perception of those involved in this process.

\section{REFERENCES}

[1] A. Aristovnik, D. Keržič, D. Ravšelj, N. Tomaževič, and L. Umek, "Impacts of the COVID-19 pandemic on life of higher education students: A global perspective," Sustainability (Switzerland), vol. 12, no. $20,2020$.

[2] X. Wang and S. Hegde, "Changwon son, bruce keller, alec smith, and farzan sasangohar. 2020."," Investigating Mental Health of US College Students During the COVID-19 Pandemic: Cross-Sectional Survey Study." Journal of Medical Internet Research, vol. 22, no. 9, p. e22817.

[3] M. Fawaz and A. Samaha, "E-learning: Depression, anxiety, and stress symptomatology among lebanese university students during covid-19 quarantine," in Nursing forum, vol. 56, no. 1. Wiley Online Library, 2021, pp. 52-57.

[4] C. A. R. Collazo and R. Hernández, "El estrés académico: una revisión crítica del concepto desde las ciencias de la educación," Revista electrónica de psicología Iztacala, vol. 14, no. 2, pp. 1-14, 2011.

[5] H. Selye, "What is stress," Metabolism, vol. 5, no. 5, pp. 525-530, 1956

[6] B. R. García, M. d. P. G. Arrieta, and A. L. E. B. Montagut, "Estresores académicos percibidos por estudiantes pertenecientes a la escuela de enfermería de ávila, centro adscrito a la universidad de salamanca," RevistaEnfermeríaCyL, vol. 6, no. 2, pp. 98-105, 2014.

[7] G. M. G. Vargas, "Factores asociados al rendimiento académico en estudiantes univer-sitarios, una reflexión desde la calidad de la educación superior pública," Revista educación, vol. 31, no. 1, pp. 43-63, 2007.

[8] R. Castillo, G. J. G. Walker, and J. G. D. Castillo, "Influencia del estrés en el rendimiento académico de un grupo de estudiantes universitarios," Educación y ciencia, vol. 4, no. 43, pp. 31-40, 2015.

[9] J. V. Conti, A. M. Mas, and P. P. Sampol, "Diferencias de estrés y afrontamiento del mismo según el género y cómo afecta al rendimiento académico en estudiantes universitarios," Contextos educativos: Revista de educación, no. 22, pp. 181-195, 2018.

[10] J. W. Oketch-Oboth and L. O. Okunya, "The Relationship Between Levels of Stress and Academic Performance Among University of
Nairobi Students," International Journal of Learning and Development, vol. 8 , no. 4,2018

[11] L. Prifti and E. Rapti, "The relationship between attachment, stress and academic success in Albanian students," Journal of Educational and Social Research, vol. 8, no. 2, 2018.

[12] A. K. Bolatov, T. Z. Seisembekov, A. Z. Askarova, R. K. Baikanova, D. S. Smailova, and E. Fabbro, "Online-learning due to covid-19 improved mental health among medical students," Medical science educator, vol. 31, no. 1, pp. 183-192, 2021.

[13] S. P. Burudi, J. Wasike, and L. Ndegwa, "Desafíos que enfrentan las bibliotecas académicas en la utilización de dispositivos móviles en el acceso y uso de la información en la universidad de kenyatta y la universidad de nairobi en kenia," African Journal of Education, Science and Technology.

[14] R. M. Oducado and H. Estoque, "Online learning in nursing education during the covid-19 pandemic: Stress, satisfaction, and academic performance," Journal Of Nursing Practice, vol. 4, no. 2, pp. 143-153, 2021

[15] Dawood Ahmad, Iftikhar Ahmad Baig, and Namra Munir., "Relación del rendimiento académico con el estrés percibido y el índice de masa corporal." Dilemas contemporáneos: Educación, Política y Valores, aug 2019.

[16] C. Son, S. Hegde, A. Smith, X. Wang, and F. Sasangohar, "Effects of covid-19 on college students' mental health in the united states: Interview survey study," Journal of medical internet research, vol. 22, no. 9, p. e21279, 2020

[17] S. F. Abdullah, N. A. Shah, and R. M. Idaris, "Stress and its relationship with the academic performance of higher institution students," International Journal of Advanced Research in Education and Society, vol. 2, no. 1 , pp. 61-73, 2020 .

[18] S. Tejedor, L. Cervi, F. Tusa, and A. Parola, "Education in times of pandemic: Reflections of students and teachers on virtual university education in Spain, Italy and Ecuador," Revista Latina de Comunicacion Social, vol. 2020, no. 78, 2020.

[19] Y. Chandra, "Online education during covid-19: perception of academic stress and emotional intelligence coping strategies among college students," Asian education and development studies, 2020.

[20] X. Li, P. Fu, C. Fan, M. Zhu, and M. Li, "Covid-19 stress and mental health of students in locked-down colleges," International Journal of Environmental Research and Public Health, vol. 18, no. 2, p. 771, 2021.

[21] S. S. Changwon, "H. \& et al. 2020. effects of covid-19 on college students' mental health in the united states: Interview survey study," Journal of medical internet research, vol. 22.

[22] J. Brannen, "Mixing methods: The entry of qualitative and quantitative approaches into the research process," International Journal of Social Research Methodology: Theory and Practice, vol. 8, no. 3, 2005.

[23] A. Jarde, J. M. Losilla, and J. Vives, "Methodological quality assessment tools of non-experimental studies: A systematic review," Anales de Psicología/Annals of Psychology, vol. 28, no. 2, 2012.

[24] D. Manrique-Millones, R. Millones-Rivalles, and O. Manrique-Pino, "The sisco inventory of academic stress: Examination of its psychometric properties in a peruvian sample," Ansiedad y Estrés, vol. 25, no. 1, pp. $28-34,2019$.

[25] L. O. O. Ugarte, S. F. Morales-Hernández, and M. K. Solano-Jáuregui, "Evidencias psicométricas de inventario sisco sv-21 para el estudio del estrés académico en universitarios peruanos," Propósitos y Representaciones, vol. 9, no. 2, p. 647, 2021.

[26] E. C. Barboza and L. R. Miranda, "Análisis de confiabilidad y validez de un cuestionario sobre entornos personales de aprendizaje (ple)," Ensayos Pedagógicos, vol. 13, no. 1, pp. 71-106, 2018.

[27] I. Iraola-Real, L. K. H. Sarmiento, C. M. Sanchez, and C. Andersson, "Mathematical self-efficacy and collaborative learning strategies in engineering career aspirants," in The International Conference on Advances in Emerging Trends and Technologies. Springer, 2020, pp. 127-136.

[28] I. Iraola-Real and M. Gonzales-Macavilca, "Anxiety and poor performance facing exams and studying mathematics: Predictive research on applicants to the universidad nacional de ingenieria of lima (peru)," in 2020 IEEE World Conference on Engineering Education (EDUNINE). IEEE, 2020, pp. 1-4.

[29] E. F. Medina, Y. P. Somoza, L. Andrade-Arenas, J. C. Zavaleta, R. Y. Alva, and S. V. Vargas, "Analysis of distance learning in the professional school of systems engineering and informatics," International Journal of Advanced Computer Science and Applications, vol. 12, no. 7, 2021. [Online]. Available: http://dx.doi.org/10.14569/IJACSA.2021.0120763

[30] M. C. Pascoe, S. E. Hetrick, and A. G. Parker, "The impact of stress on students in secondary school and higher education," International Journal of Adolescence and Youth, vol. 25, no. 1, pp. 104-112, 2020. 
[31] M. E. Silva-Ramos, María Fernanda; López-Cocotle, José Juan; Columba Meza-Zamora, "Estrés académico en estudiantes universitarios Investigación y Ciencia - 2020," Investigación y Ciencia, pp. vol.28,num.79,2020,pp75-83, 2020. [Online]. Available: https://www.redalyc.org/articulo.oa?id=67462875008

[32] S. E. Piemontesi, D. E. Heredia, L. A. Furlan, J. S. Rosas, and M. Martínez, "Ansiedad ante los exámenes y estilos de afrontamiento ante el estrés académico en estudiantes universitarios," Anales de Psicología/Annals of Psychology, vol. 28, no. 1, pp. 89-96, 2012.

[33] R. E. Encina, L. B. Meza, and M. Auchter, "Estres academico percibido por los estudiantes que finalizan el primer año de licenciatura en enfermeria de la UNNE TT - Academic stres perceived by students that finish their first year of bachelor degree in nursing from the UNNE,' Notas enferm. (Córdoba), vol. 18, no. 32, pp. 27-32, 2018. [Online]. Available: https://revistas.unc.edu.ar/index.php/notasenf/article/view/ 22744/22355
[34] D. Córdova and E. Irigoyen, "Estrés y su Asociación en Rendimiento Académico en los Estudiantes de la Facultad de Medicina desde primero a octavo nivel de la PUCE, sede Quito en el periodo correspondiente de Enero a Mayo 2015," Ph.D. dissertation, 2015.

[35] G. Boullosa Galarza, "Facultad de letras y ciencias humanas," Ph.D. dissertation, 2013. [Online]. Available: https://n9.cl/4187a

[36] A. B. MacÍas, "El estrés académico en alumnos de maestría y sus variables moduladoras: Un diseño de diferencia de grupos," Avances en Psicologia Latinoamericana, vol. 26, no. 2, pp. 270-289, 2008.

[37] S. A. Díaz Azuara and C. R. Fierro Santillán, "Aplicación de un e-cuestionario de eustrés y distrés académicos socioformativos en estudiantes de educación media superio," Eutopía, vol. 11, no. 28, pp. 22-28, 2018. [Online]. Available: http://revistas.unam.mx/index.php/eutopia/article/view/65904

[38] N. Sohail, "Stress and academic performance among medical students," J Coll Physicians Surg Pak, vol. 23, no. 1, pp. 67-71, 2013. 